Kansas State University Libraries

New Prairie Press

\title{
STABILITY ANALYSIS FOR YIELD AND SEED QUALITY OF SOYBEAN [Glycine max (L.) Merril] ACROSS DIFFERENT ENVIRONMENTS IN EASTERN SOUTH DAKOTA
}

Kaushal Raj Chaudhary

Jixiang Wu

Follow this and additional works at: https://newprairiepress.org/agstatconference

Part of the Agriculture Commons, and the Applied Statistics Commons

\section{c) (1) () $\Theta$}

This work is licensed under a Creative Commons Attribution-Noncommercial-No Derivative Works 4.0 License.

\section{Recommended Citation}

Chaudhary, Kaushal Raj and Wu, Jixiang (2012). "STABILITY ANALYSIS FOR YIELD AND SEED QUALITY OF SOYBEAN [Glycine max (L.) Merril] ACROSS DIFFERENT ENVIRONMENTS IN EASTERN SOUTH DAKOTA," Conference on Applied Statistics in Agriculture. https://doi.org/10.4148/2475-7772.1033

This is brought to you for free and open access by the Conferences at New Prairie Press. It has been accepted for inclusion in Conference on Applied Statistics in Agriculture by an authorized administrator of New Prairie Press. For more information, please contact cads@k-state.edu. 


\title{
TITLE: STABILITY ANALYSIS FOR YIELD AND SEED QUALITY OF SOYBEAN [Glycine max (L.) Merril] ACROSS DIFFERENT ENVIRONMENTS IN EASTERN SOUTH DAKOTA
}

\author{
Kaushal Raj Chaudhary ${ }^{1}$ and Jixiang $\mathrm{Wu}^{2}$ \\ Department of Mathematics and Statistics ${ }^{1}$, Plant Science Department ${ }^{2}$ \\ South Dakota State University, Brookings, SD, 57007
}

\begin{abstract}
:
Genotype-environment interaction has always been an important and challenging issue for plant breeders in developing desirable varieties. Determination of genotype and environment is common in breeding program as it helps to find out the genotypes that have wide or specific adaptability across various environmental conditions. In this study, fifteen varieties of soybean were evaluated for stability of grain yield (ton/ha), protein content (\%), and oil content (\%) at six different locations of Eastern South Dakota in 2011.

Mixed linear model and Additive main effects and multiplicative interactions (AMMI) were applied to detect genotype-by-environment $\left(\mathrm{G}^{*} \mathrm{E}\right)$ interactions and stability of each variety regarding these three traits. Variance components for genotypic and $\mathrm{G}^{*} \mathrm{E}$ interaction effects were significant for all these three traits, indicating that the tested genotypes ranked differently at these locations. Based on AMMI analysis, genotypes HEFTY H15Y12 and HEFTY H19Y12 for grain yield, genotypes HEFTY H12Y12, SD 2172, NORTHSTAR 1325R2, and NORTHSTAR 1726NR2 for protein content, and genotypes HEFTY H12Y12 and NUTECH 6145 for oil content had general adaptability under the conditions of Eastern South Dakota.
\end{abstract}

Key words: Soybean, AMMI analysis, G*E interaction, PC, biplot analysis 


\section{$\underline{1 . \text { Introduction }}$}

Soybean [(Glycine max. L) Merril] is a "Miracle bean” having a great industrial value (Hossain et al, 2003). It is the highest protein (40\%) containing food crops and is second only to groundnut in terms of oil content (20\%) among food legumes. Soybean supplies about one fourth of world's edible oil and two third of world's protein meal production (Golbitz, 2001). Soybean protein has an excellent balance of amino acids compared with other vegetable proteins (Wolf and Cowan, 1975). It is highly sensitive to photoperiod, temperature, and elevation (Ashraf et al 2010). Breeding cultivars less sensitive to photoperiod and to temperature variation is desirable for adaptation to a wider sowing area wider range. Therefore there is a great need to develop improved soybean varieties which should show stable performance over a series of environments. Yield, protein, and oil contents are three major attributes which are specially considered by soybean breeders, farmers, and marketers. Investigating the stability of soybean varieties to be released regarding these three traits is important. These traits depend on the other various components of continuous nature, whose expression is influenced by the environmental and genetic factors and their interactions. Genotype and environment interaction plays a key role in phenotypic expression, and must be estimated and considered when indicating cultivars for breeding program (Prado et al. 2001). It has been defined as the failure of genotypes to achieve the same relative performance in different environments (Baker, 1988). The presence of significant $\mathrm{G}^{*} \mathrm{E}$ for quantitative traits such as yield can seriously limit the feasibility of selecting superior genotypes (Flores et al. 1998). However, the $\mathrm{G}^{*} \mathrm{E}$ can be properly exploited to advantage through various approaches (Gauch and Zobel, 1996; Kang, 1998). Therefore, identification of yield contributing traits, and knowledge of the $\mathrm{G}^{*} \mathrm{E}$ interactions and yield stability is important for breeding new cultivars with improved adaptation to the environmental constraints prevailing in the targeted environments. 
The G*E interaction of yield and its components and other quality characters of soybean has been studied by several investigators in the past. Radi et al. (2003) evaluated five soybean genotypes under different locations and years. Their result revealed that seed yield remarkably affected by varying locations and years. Rao et al. (2002) tested 12 soybean genotypes and found significant genotype, year, and location $\left(G^{*} Y^{*} L\right)$ interaction effects for yield. Sharma et al. (1994) studied sixty genotypes of glycine max in four environments to evaluate $\mathrm{G}^{*} \mathrm{E}$ interaction as phenotypic stability using yield and quality characters. Two varieties showed high yield but below average stability for yield. Chandrakar et al. (1998) observed significant differences among genotypes and in different environments for eight characters: seed yield, oil content percentage day to 50\% flowering, days to maturity, plant height, pods/plant, and 100 seed weight. Rajanna et al. (1998) tested 24 soybean genotypes for their stability with respect to seed yield and 7 other traits (day to 50\% maturity, days taken to maturity, plant height, branches/plant, clusters/plant, pods/plant, and 100 seed weight) under different sowing dates. Significant G*E was exhibited by the genotypes for all characters. However, Yothasiri et al. (2000) found significant mean squares of genotypes for yield components. Ramana and Satyanarayana (2006) tested 16soybean genotypes for protein, oil, and yield in five different environments and found mean sum of squares due to genotype and environment (linear) were significant. Non-linear components of genotype*environment were significant for all traits. Similarly, Gurmu et al. (2007) found strong significant environment, genotypes, and G*E effects for grain yield, oil, and protein of twenty soybean genotypes tested at six different locations. Arslanglou et al. (2011) in an experiment found protein content \% and oil content \% differed significantly for genotype, environment, and their interactions among eight soybean genotypes conducted at eight sites for two years. Alghamdi (2004) found that significant genotype* 
environment for seed weight/plant (g) and seed yield (ton/ha) in an experiment of five genotypes evaluated in six different sowing dates.

In this study, fifteen soybean varieties from different seed companies were grown in six diverse locations in the eastern South Dakota in 2011. The above mentioned traits were measured. Mixed linear model was used for estimation of variance components and AMMI analysis was applied for stability of genotypes and environments for those traits. The purposes of this study are to determine those varieties which are widely adapted and those are specifically adapted to specific locations in South Dakota.

2. Materials and Methods

\section{$\underline{2.1 \text { Materials and field experiments }}$}

Fifteen soybean varieties (HEFTY H12Y12, HEFTY H13Y12, HEFTY H15Y12, HEFTY H17Y12, HEFTY H18Y12, HEFTY H19Y12, NUTECH 6118, NUTECH 6145, NUTECH 6156, NORTHSTAR 1257R2, NORTHSTAR 1325R2, NORTHSTAR 1477NR2, NORTHSTAR 1726NR2, NORTHSTAR 7159RR, SD 2171) obtained from different seed companies were grown. The experiment was conducted at six locations of the South Dakota: Warner $\left(45.4^{\circ} \mathrm{N}, 98.4^{\circ} \mathrm{W}\right)$, Northeast or South Shore $\left(45.1^{\circ} \mathrm{N}, 97.0^{\circ} \mathrm{W}\right)$, Bancroft $\left(44.4^{\circ} \mathrm{N}\right.$, $\left.97.9^{\circ} \mathrm{W}\right)$, Geddes $\left(43.3^{\circ} \mathrm{N}, 98.7^{\circ} \mathrm{W}\right)$, Southeast or Beresford $\left(43^{\circ} \mathrm{N}, 96.8^{\circ} \mathrm{W}\right)$, and Brookings ( $\left.44.3^{\circ} \mathrm{N}, 96.8^{\circ} \mathrm{W}\right)$. Planting was done using Monosem precision row crop planter with row spacing of 30 inches for all locations. The seeding rate was 165,000 seeds per acre for all varieties and locations. Each test plot consisted of 4-row plots with 20 feet long. Randomized complete block design with three replications was employed in each location. The center two rows of each plot were harvested for yield and harvesting was accomplished using a Massey Ferguson 8 X P small plot combine. Protein and oil contents were determined using a calibrated 
FOSS TECATOR model Infratec 1229 Grain Analyzer and adjusted at the moisture level of $13 \%$ for each plot.

\section{$\underline{2.2 \text { Statistical model and methodologies }}$}

Gauch and Zobel (1996) expressed the AMMI statistical model equation as follows:

$\mathrm{Y}_{\text {ger }}=\mu+\alpha_{\mathrm{g}}+\beta_{\mathrm{e}}+\sum \lambda_{\mathrm{n}}+\mathrm{y}_{\mathrm{gn}} \delta_{\mathrm{en}}+\rho_{\mathrm{ge}}+\mathrm{E}_{\text {ger }}$

Where, $Y_{\text {ger }}=$ Yield of genotype $\mathrm{g}$ in environment e for replicate $\mathrm{r}, \mu=$ Grand mean, $\alpha_{\mathrm{g}=}$ Genotype mean deviations (genotype means minus grand mean), $\beta_{\mathrm{e}}=$ Environment mean deviation, $\mathrm{n}=$ Number of PCA axes retained in the model, $\lambda_{\mathrm{n}}=$ Singular value for PCA axis $\mathrm{n}, \mathrm{y}_{\mathrm{gn}}=$ Genotype eigenvector values for PCA axis n, $\delta_{\mathrm{en}}=$ Environment eigenvector values for PCA axis $n, \rho_{\mathrm{ge}}=$ Residuals, Eger = Error.

The data were analyzed by two different methods. First we used one of mixed linear model approaches: minimum norm quadratic unbiased estimation (MINQUE) to estimate variance components. A group based jackknife method with 10 randomly divided groups was used to determine standard error for each parameter. Approximate t-test with 9 degrees of freedom 9 was used to test significance of each parameter (Miller, 1974; Wu et al., 2008). Additive main effects and multiplicative interaction (AMMI) was used to further partition the $\mathrm{G}^{*} \mathrm{E}$ for stability analysis of traits. AMMI model combines the analysis of variance for both genotype and environment main effects with principal component analysis of genotype and environment interaction. This model has been found to be useful for understanding complex interactions, gaining acuuracy, improving selection, and incresasing experimental accuracy (Gauch 1990). The results can be graphed in useful biplot that shows both main and interaction effects for both genotypes and environments (Gauch and Zobel, 1996). The ammi model has 
been extensively applied in statistical analysis of multienvironment cultivar trials (Kempton 1984, Gauch and Zobel 1997, Crossa et al., 1990).

The data analysis was accomplished using an R package GenMod developed by Dr. Jixiang Wu at South Dakota State University.

3. Result and Discussions

\subsection{Phenotypic means by locations and genotypes}

Mean grain yield, protein content and oil content were found out for different locations and genotypes.Varieties NORTHSTAR 1257R2, SD 2171, HEFTY H12Y12, HEFTY H12Y12, NORTHSTAR 1257R2, HEFTY H17Y12, and NORTHSTAR 7159RR have the highest mean grain yield in Bancroft, Brookings, Geddes, Northeast (South Shore), Southeast (Beresford), and Warner respectively. Overall, NORTHSTAR 7159RR and location Warner has the highest mean grain yield (Table 3). For protein content, varieties HEFTY H13Y12, NORTHSTAR 1257R2, HEFTY H13Y12, HEFTY H17Y12, HEFTY H19Y12, and HEFTY H13Y12 have the highest mean protein content in Bancroft, Brookings, Geddes, Northeast (South Shore), Southeast (Beresford), and Warner respectively. Variety HEFTY H19Y12 and location Northeast (South shore) had highest protein content among varieties and locations respectively (Table 4). Varieties NORTHSTAR 7159RR, NUTECH 6118, NORTHSTAR 7159RR, NUTECH 6118, NUTECH 6145, and NORTHSTAR 7159RR have the highest mean oil content in Bancroft, Brookings, Geddes, Northeast (South Shore), Southeast (Beresford), and Warner respectively. Variety NORTHSTAR 7159RR and location Geddes were the highest mean oil containing among varieties and locations respectively (Table 5).

\section{$\underline{3.2 \text { Variance components }}$}


Genotypes used for croptest trials are usually treated as fixed effects. Since mixed linear model approaches can estimate variance components and predict random effects as well (Zhu, 1989). Thus, in this study we treated all effects as random for the purpose of data analysis.

Results showed genotypic, environmental and $\mathrm{G}^{*} \mathrm{E}$ interaction effects are highly significant $(\mathrm{P}<$ 0.001) for all traits. Environmental component contributed 50\%, 64\%, and $71 \%$ to the total variation for grain yield, protein content, and oil content respectively. Similarly, genotype component contributed $6 \%, 16 \%$, and $17 \%$ of total variation while $\mathrm{G}^{*} \mathrm{E}$ comprised of $6 \%, 6 \%$, and $4 \%$ of total variation for grain yield, protein content , and oil content respectively (Table 2). Comparing to environmental effects, genotypic effects were much smaller. This is because the varieties provided by seed companies have high yield

\subsection{Stability Analysis}

Our major objective in the present study was to identify which cultivars were widely adapted to various locations in Eastern South Dakota or which were adapted to specific environments. AMMI method, which is principal component analysis based approach, was used to analyze the stability of these 15 soybean cultivars regarding grain yield, protein content, and oil content respectively. Two biplots (AMMI 1 and AMMI 2) were used to demonstrate stability of variety for each of three traits. AMMI 1 biplot of main effects are shown along abscissa and the ordinate represent first principal component (PC1) score.The basic idea of AMMI 1 biplot is to provide means to select stable high yielding varieties. AMMI 2 biplot explain the magnitude of interaction of each genotype and environment. The genotypes and environment that are farthest from the origin being more responsive fit the worst. The main purpose of AMMI 2 biplot is to identify varieties with specific environmental adaptation. 


\subsubsection{Grain Yield (ton/ha)}

In AMMI biplot 1 showing main effects means on the abscissa and principal component (PC) values as the ordinates, genotypes (environments) that appear almost on a perpendicular line have similar means and those that fall on the almost horizontal line have similar interaction patterns. Genotypes that group together have similar adaptation while environments which group together influences the genotypes in the same way. Genotypes (environments) with large PC1 scores (either positive or negative) have high interactions whereas genotypes (environments) with PC1 score near zero have small interactions. Genotypes having zero PC 1 score are less influenced by the environments and adapted to all environments. Since PC 1 scores of varieties HEFTY H19Y12 and HEFTY H15Y12 were close to zero, they were most stable genotypes that across these environments (Figure 1). However, the mean yield of genotype HEFTY H19Y12 was higher than genotype HEFTY H15Y12, hence it is more preferable although both genotypes had mean yield below average. Therefore, a stable variety might not be the highest yielding. The environments having small score had small interaction effects indicating all genotypes performed well in these locations. Warner was relatively closer to zero than rest of the locations, it was more stable. Since its mean yield is higher than other locations, this might be best location with respect to yield. Genotypes and environments with PC1 scores of the same sign produce positive interaction effects, thus higher yield of the genotype at that particular location whereas combination of the PC 1 scores of the opposite sign produce specific negative interactions. A genotype showing high positive interaction in an environment has the ability to exploit the agroecological and agro-management conditions of the specific environment and is therefore best suited to that environment. 
Ammi 2 biplot presents the spatial pattern of the first two PC axes of the interaction effect corresponding to the genotypes and helps in the visual interpretation of the $G^{*} E$ pattern and identify genotypes or environments that exhibit low, medium, or high level of interaction effects (Sharma et al., 1998). PC1 and PC2 of grain yield accounted for $50.4 \%$ and $29.4 \%$ of interaction respectively. The stability of a genotype or an environment is determined by the end point of its vector from origin $(0,0)$. Genotypes near the origin are non-sensitive to environmental interactive forces, hence may be considered stable ones and those distant from origin are sensitive and have large interactions. Genotypes HEFTY H15Y12 and HEFTY H19Y12 were close to the origin than any of other genotypes, hence they are most stable (Figure 2). In Ammi 2 biplot, the environment scores are joined to the origin by the site lines. Environments with short spokes (length of arrow lines) do not exert strong interactive forces. Those with long spokes (length of arrow lines) exert strong interaction. Geddes, Brookings, and North East farm (South shore) having longer spokes exert high interaction while Warner, Bancroft, and SE having shorter spokes produce weak interaction. Varieties NORTHSTAR 7159RR, HEFTY H19Y12, and NORTHSTAR 1257R2were specifically adapted to Geddes, Brookings, Bancroft respectively. Variety HEFTY H15Y12 was adapted to Warner, Bancroft, and South East farm (Beresford) (Figure 2). Bancroft and genotype NORTHSTAR 1257R2 and Geddes and genotype NORTHSTAR 7159RR had large interaction (Figure 2).

\subsubsection{Protein content}

\section{Genotypes HEFTY H12Y12, SD 2172, NORTHSTAR 1325R2, and NORTHSTAR} 1726NR2 were closer to PC1 score of zero (Figure 3). They were the most stable genotypes and were adapted to all environments. Bancroft was relatively closer to the origin than any other of the locations and all genotype can perform equally in this location. Since genotype 
NORTHSTAR 1726NR2 is coupled with proximity to origin and above average protein content percentage, it might be ideal for protein content. Genotype HEFTY H15Y12 and locations Warner and Brookings had high interactive force as they are farthest from origin towards negative PC1 score. Genotype HEFTY H19Y12 and location Geddesalso exerted strong interactive effect since they had high positive PC 1 score (Figure 3).

In AMMI 2 biplot, PC1 and PC2 consisted of 39.5\% and $29.2 \%$ of interaction respectively. All locations have high interactive forces as they are far away from the origin and Genotype NORTHSTAR 1726NR2 is most stable because of its closeness to origin. From the projection line, NORTHSTAR 1477NR2, NUTECH6156, NORTHSTAR1726NR2, NORTHSTAR 7159RR, andNUTECH6118 were specifically adapted to North East farm (South shore),Warner, Brookings, Geddes, and Bancroft respectively. Among them, Geddes and NORTHSTAR 7159RR had large interaction (Figure 4).

\section{$\underline{3.3 .3 \text { Oil content } \%}$}

According to AMMI 1 biplot, PC1 scores for genotypes HEFTY H12Y12 and NUTECH 6145 were close to zero; hence they were the most stable (Figure 5). Genotype NUTECH 6145 being far above from the average oil content percentage was more ideal than HEFTY H12Y12. PC1 score for Warner being close to the zero was the stable environment where mostly all genotypes could perform equally in this environment for oil content. Geddes and North East (South shore) farm had large interaction effect because of high positive and high negative PC1 score respectively. Genotypes NUTECH 6118 and NORTHSTAR 1257R2 with high negative PC 1 score were indicative of possible large interaction effect. In AMMI 2 biplot, PC 1 and PC2 comprised of $52.8 \%$ and $20.9 \%$ of interaction respectively. Varieties NORTHSTAR 1257R2, HEFTY H19Y12, and NORTHSTAR 7159RR, and HEFTY H18Y12 were specifically adapted 
to North East farm (South shore), Brookings, Warner, and Geddesrespectively for oil content (Figure 6).

\section{Summary}

Mixed linear model approach has been useful to detect the genotype and environment interaction croptest trials. G*E being significantly different for all the tested traits, AMMI analysis partitioned $G^{*} E$ with information about the general and specific adaptation of varieties in different environments. Genotypes HEFTY H15Y12 and HEFTY H19Y12 for grain yield, genotypes HEFTY H12Y12, SD 2172, NORTHSTAR 1325R2, and NORTHSTAR 1726NR2 for protein content, and genotypes HEFTY H12Y12 and NUTECH 6145 for oil content were found to have general adaptation in eastern South Dakota. Genotypes NORTHSTAR 7159 RR, the highest grain yielding had strong adaptation to Geddes for grain yield and protein content.Genotype HEFTY H19Y12 had strong specific adaptation to Brookings.

\section{Acknowledgements}

This study was financially supported by South Dakota Soybean Research and Promotion Council, Department of Plant Science, and Department of Mathematics and Statistics, South Dakota State University. We are also thankful to Mauricio Erazo-Barradas and Yi Xu for help in sample and data collection

\section{$\underline{\text { 6. References }}$}

Alghamdi, S.S. 2009. Yield stability of some soybean genotypes across diverse environments. Pak. J. Biol. Sci. 7: 2109-2214.

Arslanogu, F., S. Aytac, and E. K. Oner. 2011). Effect of genotype and environment interactions on oil and protein content of soybean (Glycine max (L.) Merrill) seed. Afr. J. Biotechnol.10: 18409-18417.

Ashraf, M., Z. Iqbal, M. Arshad, A. Waheed, M. A. Glufran, Z. Chaudhry, and D. Baig. 2010. Multi-environment response in seed yield of soybean [Glycine max (L.) Merril], genotypes through GGE biplot technique. Pak. J. Bot. 42: 3899-3905. 
Baker, R.J. 1998. Test for crossover genotype-environmental interactions. Can. J. Plant Sci. 68:405-410.

Chandrakar, P.K., S. Rajeev, S. K. Agrawal, S.S. Rao, and R. Shrivastava.1998. Stability analysis of soybean (Glycine max. L. Merril) varieties in rice zone of Madhya Pradesh. J. Oilseeds Res. 15:247-249.

Crossa J., H. G. Gauch, and R. W. Zobel. AMMI analysis of two international maize cultivar trails. Crop Sci. 30: 493-500.

Ferreira, D.F., , C. G. B. Demetrio, B. F. J. Manly, A. A. Machado, R. Venkovsky. 2006. Statistical models in agriculture: Biometrical methods for evaluating phenotypic stability in plant breeding. Cerner.12: 373-388.

Flores, F., M. T. Moreno, and J. I. Cubero. 1998. A comparison of the univariate and multivariate methods to analyze $\mathrm{G}^{*} \mathrm{E}$ interaction. Field Crop Res. 56:271-286.

Gauch, H.G. and R.W. Zobel.1996. AMMI Analysis of Yield Trials. In: Genotype-byEnvironment Interaction, Kang, M.S. and H.G. Gauch (Eds.). Boca Raton CRC, New York, USA. pp: 85-122.

Gauch, H.G. and R. W. Zobel. 1997. Identifying mega environments and targeting genotypes. Crop Sci. 37:311-316.

Golbitz, P. (2001). Soya and Oilseed Blue Book. 2001. Soyatech Inc. Bar Habor, ME.

Gurmu, F., H. Mohammed, and G. Alemaw. 2009. Genotype and environment interaction and s stability of soybean for grain yield and nutritional quality. Afr. crop sci. j.17:87-99.

Hossain, M.A., L. Rahman, and A. K. M. Shamsuddin. 2003. Genotype and environment interaction and stability analysis in soybean. J. biol. Sci.3:1026-1031.

Kang, M.S.1998. Using genotype-by-environment interaction for crop cultivar development. Adv. Agron. , 35: 199-240.

Kempton, R.A. 1984. The use of biplot in interpreting variety by environment interactions. J Agric. Sci., 103: 123-135.

Wu, J., J. N. Jenkins, and J.C. McCarty Jr. 2009. Testing variance components by two jackknife methods. In: Applied Statistics in Agriculture Conference Proceedings, April 27-29, 2008, Manhattan, KS. pp. 1-17.

Miller, R. G. 1974. The Jackknife-A Review. Biometrika. 61:1-25 
Prado, E.E., D. M. Hiromoto, V. P. C. Godinho, M. M. Utumi and A. R. Ramalho. 2001. Adaptabilidade e estabilidade de cultivares de soja em cinco épocas de plantio no cerrado de Rondônia. Pesquisa Agropecuária Brasileira 36: 625-635.

Radi M.M, M.A. EI-basai, Safia, T. Abdalla, A. E. sharaf, and E F. Desouski. 1993. Estimating of stability parameters of yield of some soybean cultivars. J. Agric. Res., TantaUniv., 11: 86-91.

Rajanna M.P., S. R. Vishwanatha, R. S. Kulkarni, and S. Ramesh.1999. Stability analysis for seed yield and its components in soybean (Glycine max (L.) Meriil). Crop Res. Hisar 18: 437-442.

Ramana, M.V. and A. Satyanarayana. 2005. Stability of yield and its components in soybean (Glycine max. L. Merrill). J. Oilseeds Res. 22:18-21.

Rao, M.S.S, B. G. Mullinix, M. Rangappa, E. Cebert, A. S Bhagasari, V. T. Sapra, J. M. Joshi and R. B. Dadson. 2002.Genotype and environment interactions and yield stability of food-grade soybean genotypes. Agron. J. 94:72-80.

Sabaghnia, N., H. Dehghani, and S. H. Sobaghpour, 2006. Non parametric methods for interpreting genotype and environment interaction in lentil genotypes. Crop Sci.46:11001116.

Shrama, P.K., P. K. Gupta, and O. P. Govila.1998. AMMI analysis of pearl millet yield trial. Indian Journal of Genetics, 58:183-192.

Wolf, W.J. and Cowan, J.C. (1975). Soybeans as Food Source. Rev. ed. CRC Press, Cleveland, $\mathrm{OH}$.

Yathasiri, A., T. Somwang, Y. Amuay, S. Teera. 2000. Stability of soybean genotypes in central plain Thailand. Kasetsart J. Nat. Sci. 34:315-322.

Zhu, J., 1989. Estimation of genetic variance components in the general mixed model. Ph.D. Dissertation, North Carolina State University, Raleigh, U.S.A. (Diss. Abstr. DA8924291). 
Table1: Varity with corresponding replication and plot number

\begin{tabular}{lrrrr}
\hline Variety & Trt. No. & \multicolumn{3}{c}{ Rep. and Plot No. } \\
\hline \hline HEFTY H12Y12 & 1 & 1004 & 2013 & 3001 \\
HEFTY H13Y12 & 2 & 1011 & 2009 & 3002 \\
HEFTY H15Y12 & 3 & 1009 & 2015 & 3006 \\
HEFTY H17Y12 & 4 & 1002 & 2006 & 3008 \\
HEFTY H18Y12 & 5 & 1012 & 2005 & 3013 \\
HEFTY H19Y12 & 6 & 1014 & 2001 & 3012 \\
NUTECH 6118 & 7 & 1013 & 2012 & 3005 \\
NUTECH 6145 & 8 & 1010 & 2008 & 3015 \\
NUTECH 6156 & 9 & 1008 & 2010 & 3009 \\
NORTHSTAR 1257R2 & 10 & 1003 & 2004 & 3007 \\
NORTHSTAR 1325R2 & 11 & 1006 & 2007 & 3003 \\
NORTHSTAR 1477NR2 & 12 & 1007 & 2014 & 3010 \\
NORTHSTAR 1726NR2 & 13 & 1005 & 2003 & 3004 \\
NORTHSTAR 7159RR & 14 & 1015 & 2002 & 3011 \\
SD 2171 & 15 & 1001 & 2011 & 3014 \\
\hline
\end{tabular}

Trt. No=Treatment Number, Rep. $=$ Replication

Table2:Variance Components , estimate, and standard error of yield (ton/ha), protein content $\%$ and oil content \%

\begin{tabular}{|c|c|c|c|c|c|c|}
\hline \multirow{2}{*}{$\begin{array}{l}\text { Variance } \\
\text { Components }\end{array}$} & \multicolumn{2}{|c|}{ Yield(ton/ha) } & \multicolumn{2}{|c|}{ Protein \% } & \multicolumn{2}{|c|}{ Oil \% } \\
\hline & Estimate & SE & Estimate & SE & Estimate & $\mathrm{SE}$ \\
\hline Var(ENV) & 0.19 & 0.01 & 3.14 & 0.098 & 1.14 & 0.02 \\
\hline Var(GEN) & 0.021 & 0.002 & 0.76 & 0.03 & 0.27 & 0.008 \\
\hline Var(ENV:GEN) & 0.024 & 0.01 & 0.28 & 0.042 & 0.06 & 0.007 \\
\hline Var(ENV:Rep) & 0.025 & 0.007 & 0.13 & 0.026 & 0.017 & 0.0036 \\
\hline $\mathrm{Ve}$ & 0.12 & 0.017 & 0.6 & 0.036 & 0.11 & 0.006 \\
\hline
\end{tabular}

Var=Variance, ENV=Environment, GEN=Genotype, Rep=Replication, SE=Standard error, $\mathrm{Ve}=$ Error variance 
Table 3: Mean grain yield (ton/ha) of fifteen soybean genotypes tested at six locations of eastern South Dakota in 2011.

\begin{tabular}{lccccccc}
\hline \multirow{2}{*}{ Genotypes } & \multicolumn{7}{c}{ Environments } \\
\cline { 2 - 7 } & Bancroft & Brookings & Geddes & NE & SE & Warner & Mean \\
\hline \hline HEFTY H12Y12 & 3.83 & 3.56 & 4.65 & 3.17 & 3.17 & 4.00 & 3.73 \\
HEFTY H13Y12 & 3.96 & 3.86 & 3.35 & 3.16 & 3.31 & 4.17 & 3.64 \\
HEFTY H15Y12 & 3.97 & 3.68 & 3.48 & 2.70 & 3.36 & 3.89 & 3.51 \\
HEFTY H17Y12 & 3.70 & 3.70 & 3.34 & 2.85 & 3.43 & 4.35 & 3.56 \\
HEFTY H18Y12 & 3.75 & 3.63 & 3.41 & 2.40 & 3.31 & 3.89 & 3.40 \\
HEFTY H19Y12 & 3.71 & 3.81 & 3.44 & 2.63 & 3.22 & 3.77 & 3.43 \\
NUTECH 6118 & 3.99 & 3.99 & 3.26 & 2.98 & 3.50 & 4.22 & 3.66 \\
NUTECH 6145 & 3.47 & 3.99 & 3.56 & 2.19 & 3.08 & 3.97 & 3.38 \\
NUTECH 6156 & 3.10 & 3.30 & 3.40 & 2.66 & 3.10 & 3.72 & 3.21 \\
NORTHSTAR & 4.31 & 3.99 & 3.51 & 2.91 & 3.59 & 4.04 & 3.73 \\
1257R2 & & & & & & & \\
NORTHSTAR & 3.89 & 4.07 & 3.18 & 3.14 & 3.34 & 4.03 & 3.61 \\
1325R2 & & & & & & & \\
NORTHSTAR & 3.48 & 3.12 & 3.50 & 2.80 & 3.12 & 4.02 & 3.34 \\
1477NR2 & & & & & & & \\
NORTHSTAR & 4.03 & 4.23 & 3.43 & 2.97 & 3.64 & 4.44 & 3.79 \\
1726NR2 & & & & & & & \\
NORTHSTAR & 3.87 & 4.26 & 4.16 & 3.04 & 3.37 & 4.25 & 3.83 \\
7159RR & 3.89 & 4.27 & 3.52 & 2.14 & 3.56 & 4.11 & 3.58 \\
SD 2171 & 3.80 & 3.83 & 3.55 & 2.78 & 3.34 & 4.06 & \\
Mean &
\end{tabular}

$\mathrm{NE}=$ North East Farm (South shore), $\mathrm{SE}=$ South East Farm (Beresford) 
Table 4: Mean protein content \% of fifteen soybean genotypes tested at six locations of eastern South Dakota in 2011.

\begin{tabular}{|c|c|c|c|c|c|c|c|}
\hline \multirow[b]{2}{*}{ Genotypes } & \multicolumn{7}{|c|}{ Environments } \\
\hline & Bancroft & Brookings & Geddes & $\mathrm{NE}$ & SE & Warner & Mean \\
\hline HEFTY H12Y12 & 30.90 & 30.03 & 27.83 & 32.63 & 32.13 & 30.86 & 30.73 \\
\hline HEFTY H13Y12 & 33.83 & 31.43 & 29.97 & 34.30 & 33.90 & 32.60 & 32.67 \\
\hline HEFTY H15Y12 & 31.80 & 32.00 & 27.06 & 34.20 & 32.40 & 33.10 & 31.76 \\
\hline HEFTY H17Y12 & 31.78 & 30.93 & 29.40 & 34.37 & 34.60 & 31.87 & 32.16 \\
\hline HEFTY H18Y12 & 31.43 & 29.80 & 28.47 & 34.30 & 33.17 & 31.30 & 31.41 \\
\hline HEFTY H19Y12 & 33.57 & 31.20 & 31.00 & 34.01 & 34.80 & 32.57 & 32.87 \\
\hline NUTECH 6118 & 31.90 & 30.76 & 29.13 & 32.30 & 32.33 & 31.76 & 31.36 \\
\hline NUTECH 6145 & 29.57 & 30.93 & 28.50 & 33.60 & 31.50 & 31.03 & 30.86 \\
\hline NUTECH 6156 & 30.70 & 28.73 & 26.60 & 32.50 & 32.00 & 31.03 & 30.26 \\
\hline $\begin{array}{l}\text { NORTHSTAR } \\
\text { 1257R2 }\end{array}$ & 33.60 & 31.90 & 30.10 & 34.23 & 34.13 & 33.17 & 32.86 \\
\hline $\begin{array}{l}\text { NORTHSTAR } \\
\text { 1325R2 }\end{array}$ & 32.13 & 30.23 & 28.10 & 32.57 & 33.20 & 31.87 & 31.35 \\
\hline $\begin{array}{l}\text { NORTHSTAR } \\
1477 N R 2\end{array}$ & 31.13 & 29.96 & 27.37 & 33.70 & 33.50 & 31.13 & 31.13 \\
\hline $\begin{array}{l}\text { NORTHSTAR } \\
\text { 1726NR2 }\end{array}$ & 31.60 & 31.70 & 28.80 & 33.20 & 33.67 & 31.80 & 31.80 \\
\hline $\begin{array}{l}\text { NORTHSTAR } \\
\text { 7159RR }\end{array}$ & 30.23 & 28.76 & 27.40 & 31.760 & 32.30 & 28.93 & 29.90 \\
\hline SD 2171 & 30.07 & 29.66 & 28.30 & 33.70 & 32.40 & 30.23 & 30.73 \\
\hline Mean & 31.62 & 30.53 & 28.54 & 33.43 & 33.07 & 31.55 & \\
\hline
\end{tabular}

NE= North East Farm (South shore), SE= South East Farm (Beresford) 
Table 5: Mean oil content \% of fifteen soybean genotypes tested at six locations of eastern South Dakota in 2011.

\begin{tabular}{|c|c|c|c|c|c|c|c|}
\hline \multirow[b]{2}{*}{ Genotypes } & \multicolumn{7}{|c|}{ Environments } \\
\hline & Bancroft & Brookings & Geddes & $\mathrm{NE}$ & SE & Warner & Mean \\
\hline HEFTY H12Y12 & 16.50 & 16.40 & 18.33 & 15.37 & 18.77 & 17.30 & 17.11 \\
\hline HEFTY H13Y12 & 16.30 & 17.03 & 18.13 & 15.40 & 18.06 & 17.26 & 17.03 \\
\hline HEFTY H15Y12 & 15.90 & 16.93 & 18.83 & 14.87 & 18.23 & 17.00 & 16.96 \\
\hline HEFTY H17Y12 & 17.20 & 16.97 & 18.90 & 15.83 & 18.23 & 17.70 & 17.47 \\
\hline HEFTY H18Y12 & 16.90 & 16.80 & 18.57 & 14.97 & 18.00 & 17.26 & 17.08 \\
\hline HEFTY H19Y12 & 16.03 & 16.46 & 17.27 & 15.00 & 17.30 & 16.93 & 16.50 \\
\hline NUTECH 6118 & 17.23 & 17.87 & 18.33 & 16.73 & 18.90 & 18.10 & 17.86 \\
\hline NUTECH 6145 & 18.27 & 17.50 & 19.06 & 16.37 & 19.23 & 18.06 & 18.08 \\
\hline NUTECH 6156 & 16.90 & 16.83 & 18.67 & 15.47 & 18.23 & 17.10 & 17.20 \\
\hline $\begin{array}{l}\text { NORTHSTAR } \\
\text { 1257R2 }\end{array}$ & 16.27 & 17.23 & 17.60 & 15.47 & 18.23 & 16.77 & 16.93 \\
\hline $\begin{array}{l}\text { NORTHSTAR } \\
1325 R 2\end{array}$ & 16.10 & 16.36 & 17.63 & 15.47 & 17.83 & 16.63 & 16.67 \\
\hline $\begin{array}{l}\text { NORTHSTAR } \\
1477 \text { NR2 }\end{array}$ & 16.40 & 16.53 & 18.50 & 14.83 & 17.53 & 17.33 & 16.85 \\
\hline $\begin{array}{l}\text { NORTHSTAR } \\
\text { 1726NR2 }\end{array}$ & 16.00 & 15.96 & 17.93 & 14.67 & 17.77 & 16.76 & 16.52 \\
\hline $\begin{array}{l}\text { NORTHSTAR } \\
\text { 7159RR }\end{array}$ & 17.70 & 18.10 & 19.70 & 16.50 & 19.03 & 18.87 & 18.32 \\
\hline SD 2171 & 17.17 & 17.16 & 18.73 & 15.33 & 18.10 & 17.73 & 17.37 \\
\hline Mean & 16.72 & 16.94 & 18.41 & 15.49 & 18.23 & 17.39 & \\
\hline
\end{tabular}

NE $=$ North East Farm (South shore), SE= South East Farm (Beresford) 


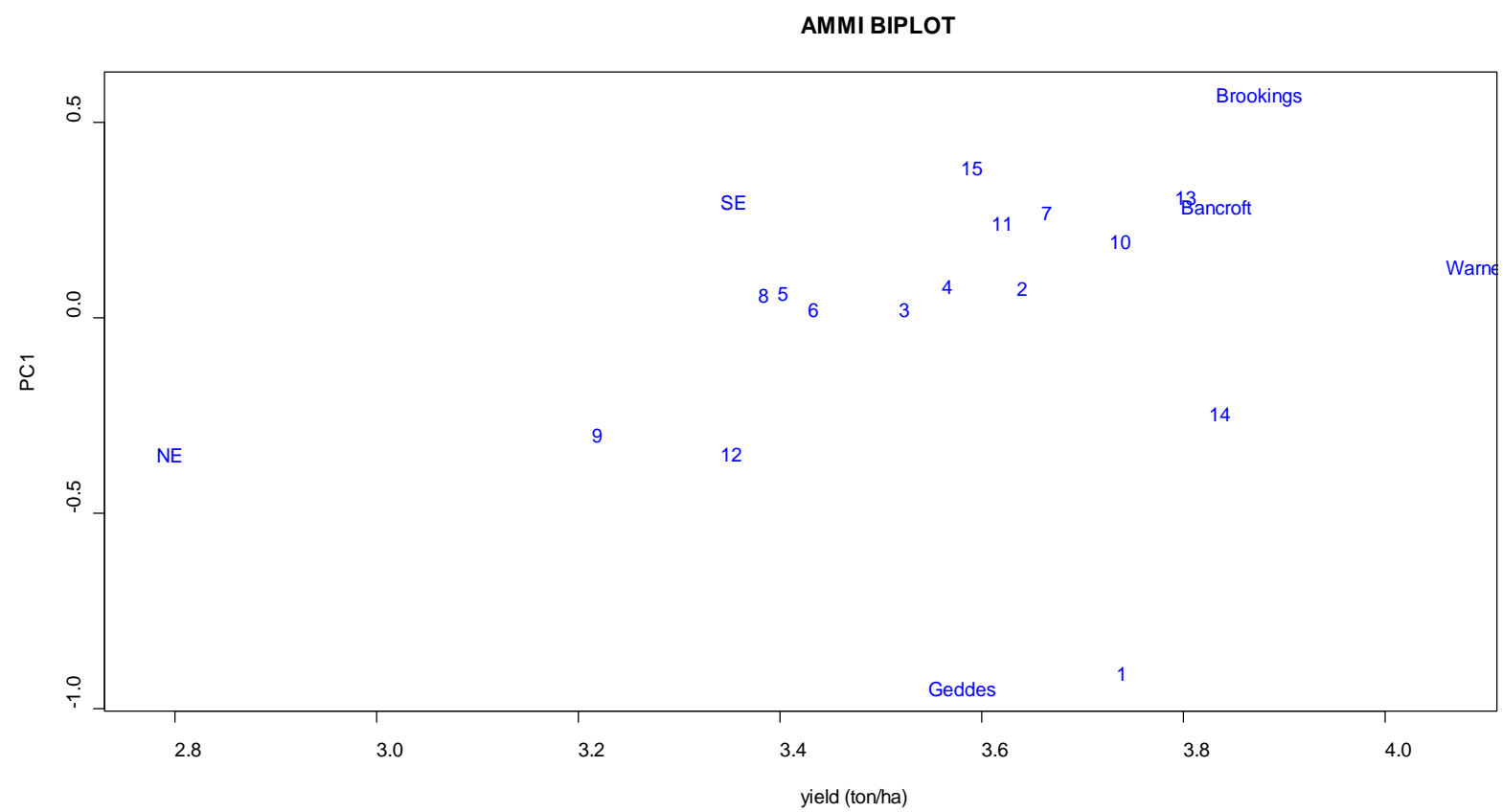

Fig. 1: AMMI1-Biplot for grain yield in soybean 1=HEFTY H12Y12, 2=HEFTY H13Y12, 3=HEFTY H15Y12, 4=HEFTY HY17Y12, 5=HEFTY H18Y12, 6=HEFTY H19Y12, 7=NUTECH 6118, 8=NUTECH 6145, 9=NUTECH 6156, 10 =NORTHSTAR 1257R2, 11=NORTHSTAR 1325R2, 12=NORTHSTAR 1477NR2, 13=NORTHSTAR 1726NR2, 14=NORTHSTAR 7159RR, 15=SD 2171 


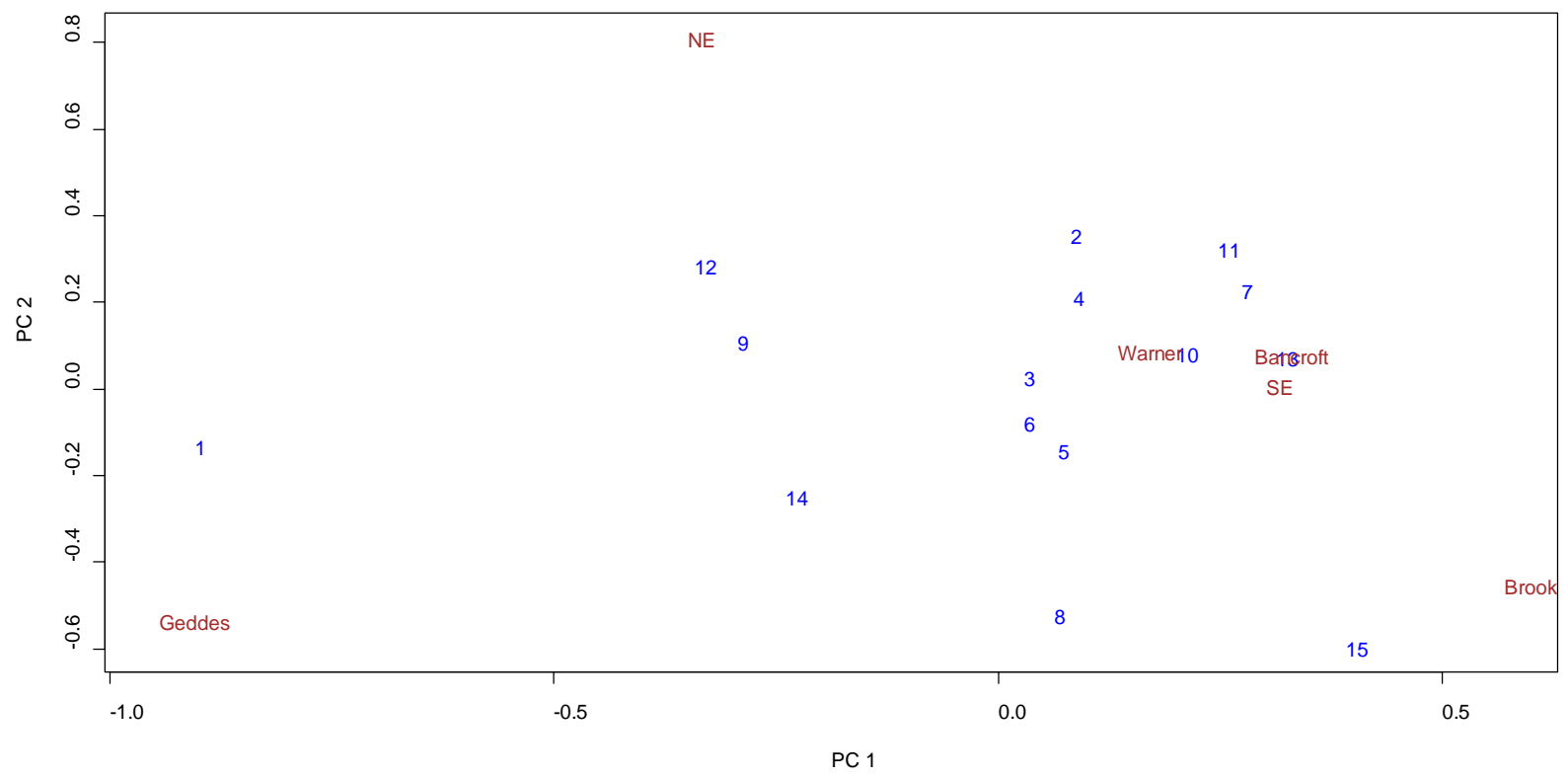

Fig. 2: AMMI 2-Biplot for grain yield in soybean 1=HEFTY H12Y12, 2=HEFTY H13Y12, 3=HEFTY H15Y12, 4=HEFTY HY17Y12, 5=HEFTY H18Y12, 6=HEFTY H19Y12, 7=NUTECH 6118, 8=NUTECH 6145, 9=NUTECH 6156, 10 =NORTHSTAR 1257R2, 11=NORTHSTAR 1325R2, 12=NORTHSTAR 1477NR2, 13=NORTHSTAR 1726NR2, 14=NORTHSTAR 7159RR, 15=SD 2171 


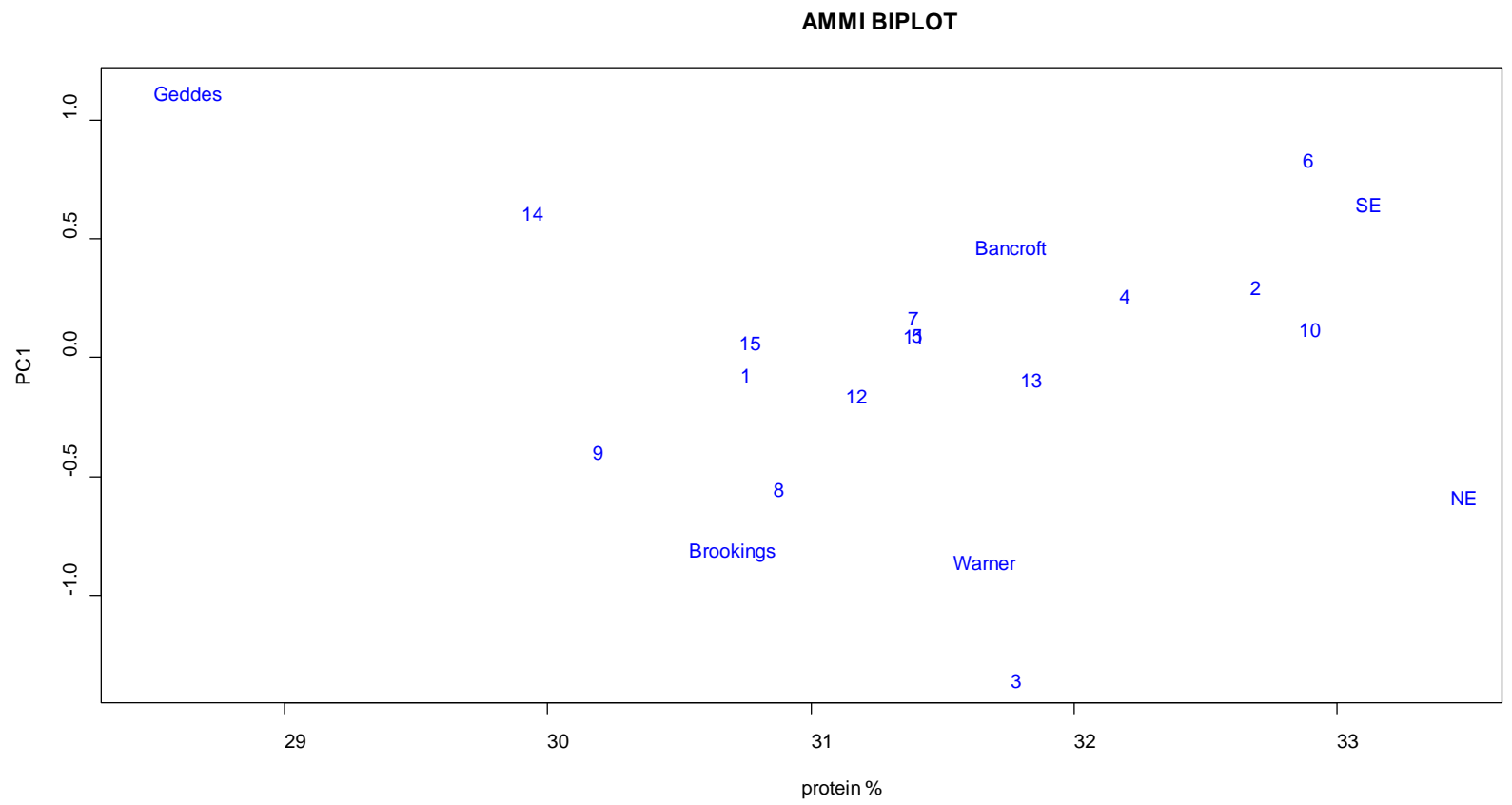

Fig. 3: AMMI 1-Biplot for protein content in soybean 1=HEFTY H12Y12, 2=HEFTY H13Y12, 3=HEFTY H15Y12, 4=HEFTY HY17Y12, 5=HEFTY H18Y12, 6=HEFTY H19Y12, 7=NUTECH 6118, 8=NUTECH 6145, 9=NUTECH 6156, 10 =NORTHSTAR 1257R2, 11=NORTHSTAR 1325R2, 12=NORTHSTAR 1477NR2, 13=NORTHSTAR 1726NR2, 14=NORTHSTAR 7159RR, 15=SD 2171 


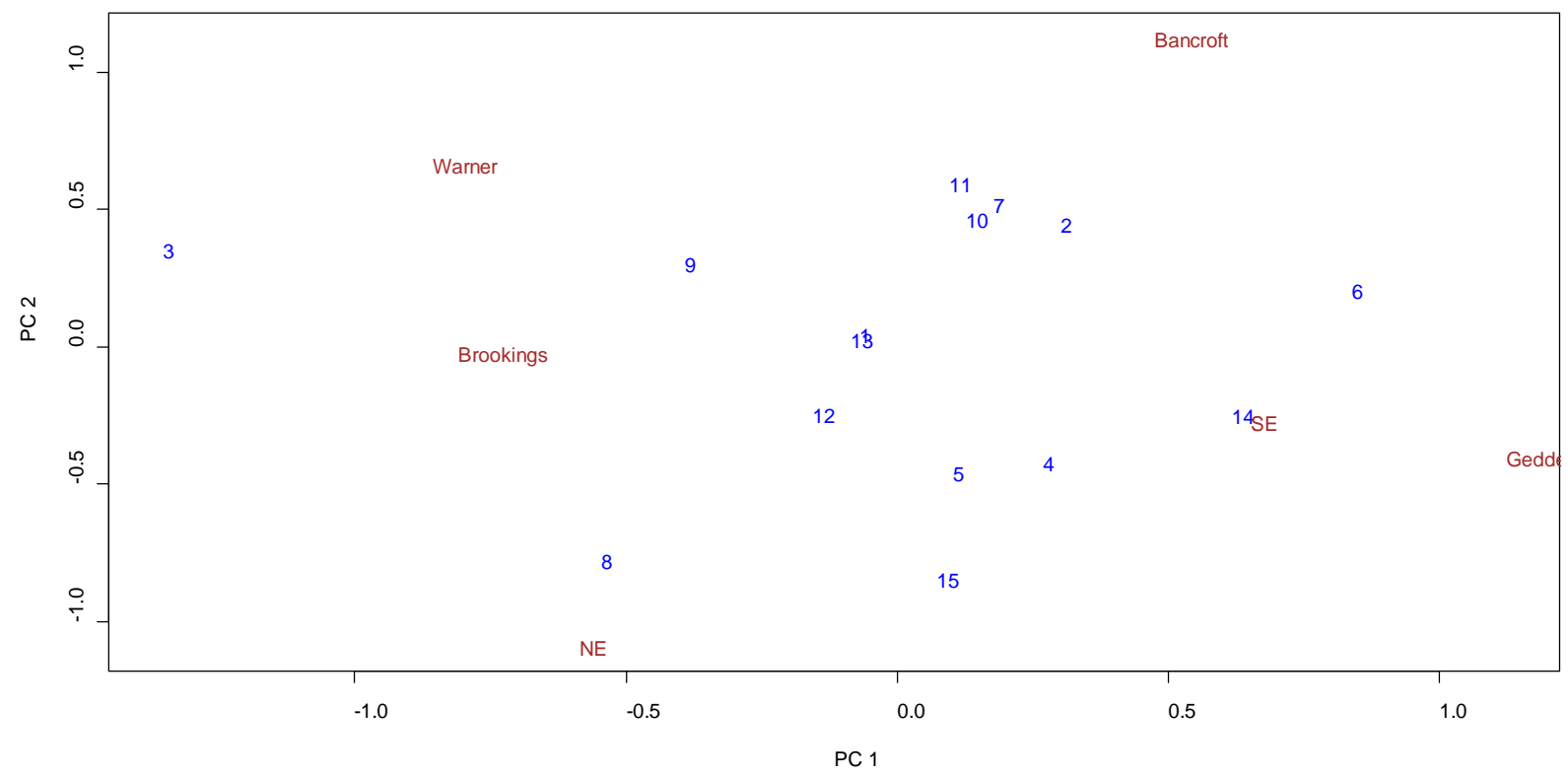

Fig. 4: AMMI 2-Biplot for protein content in soybean 1=HEFTY H12Y12, 2=HEFTY H13Y12, 3=HEFTY H15Y12, 4=HEFTY HY17Y12, 5=HEFTY H18Y12, 6=HEFTY H19Y12, 7=NUTECH 6118, 8=NUTECH 6145, 9=NUTECH 6156, 10 =NORTHSTAR 1257R2, 11=NORTHSTAR 1325R2, 12=NORTHSTAR 1477NR2, 13=NORTHSTAR 1726NR2, 14=NORTHSTAR 7159RR, 15=SD 2171 


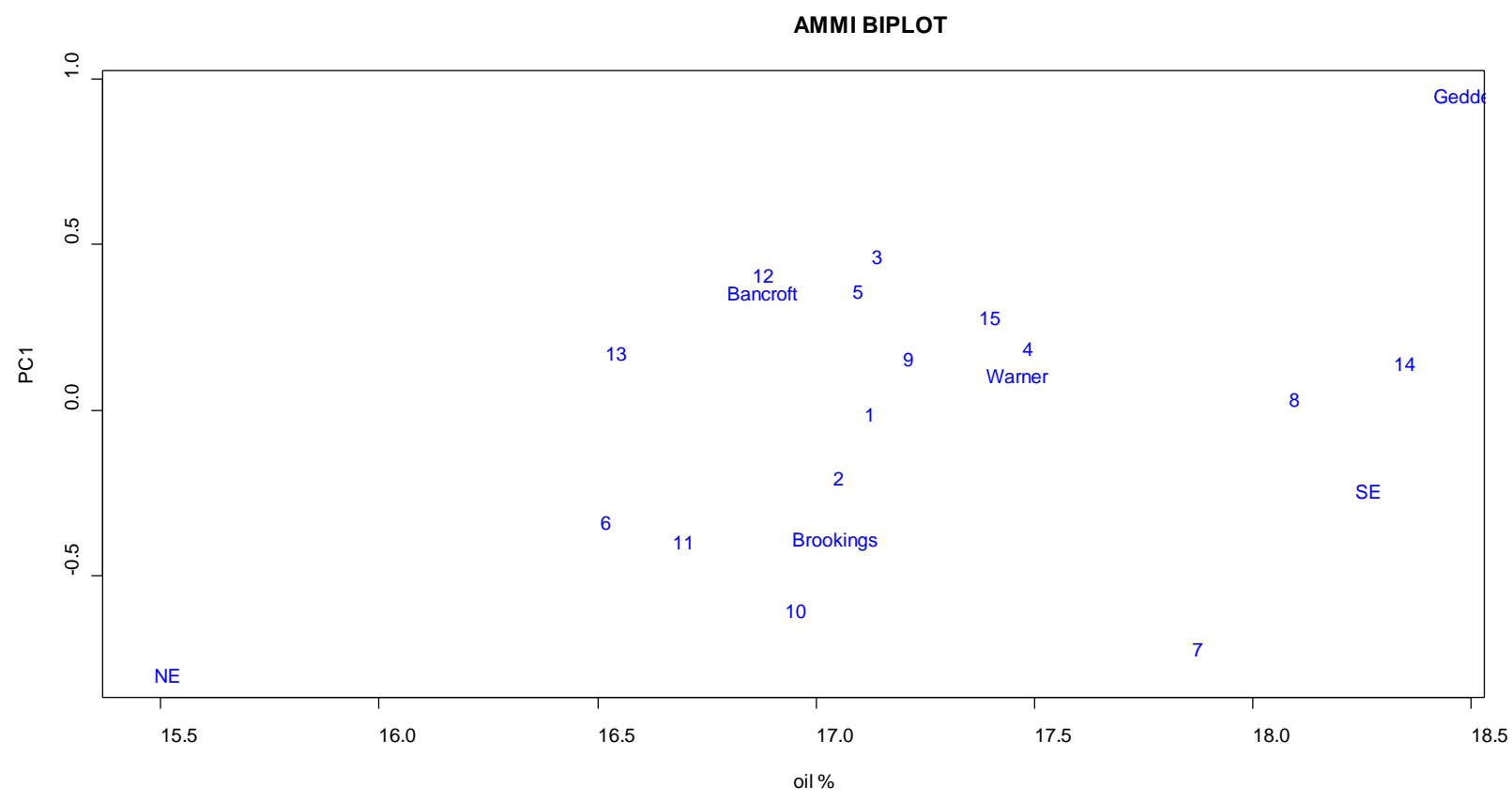

Fig. 5: AMMI 1-Biplot for oil content in soybean 1=HEFTY H12Y12, 2=HEFTY H13Y12, 3=HEFTY H15Y12, 4=HEFTY HY17Y12, 5=HEFTY H18Y12， 6=HEFTY H19Y12, 7=NUTECH 6118, 8=NUTECH 6145, 9=NUTECH 6156, 10 =NORTHSTAR 1257R2, 11=NORTHSTAR 1325R2, 12=NORTHSTAR 1477NR2, 13=NORTHSTAR 1726NR2, 14=NORTHSTAR 7159RR, 15=SD 2171 


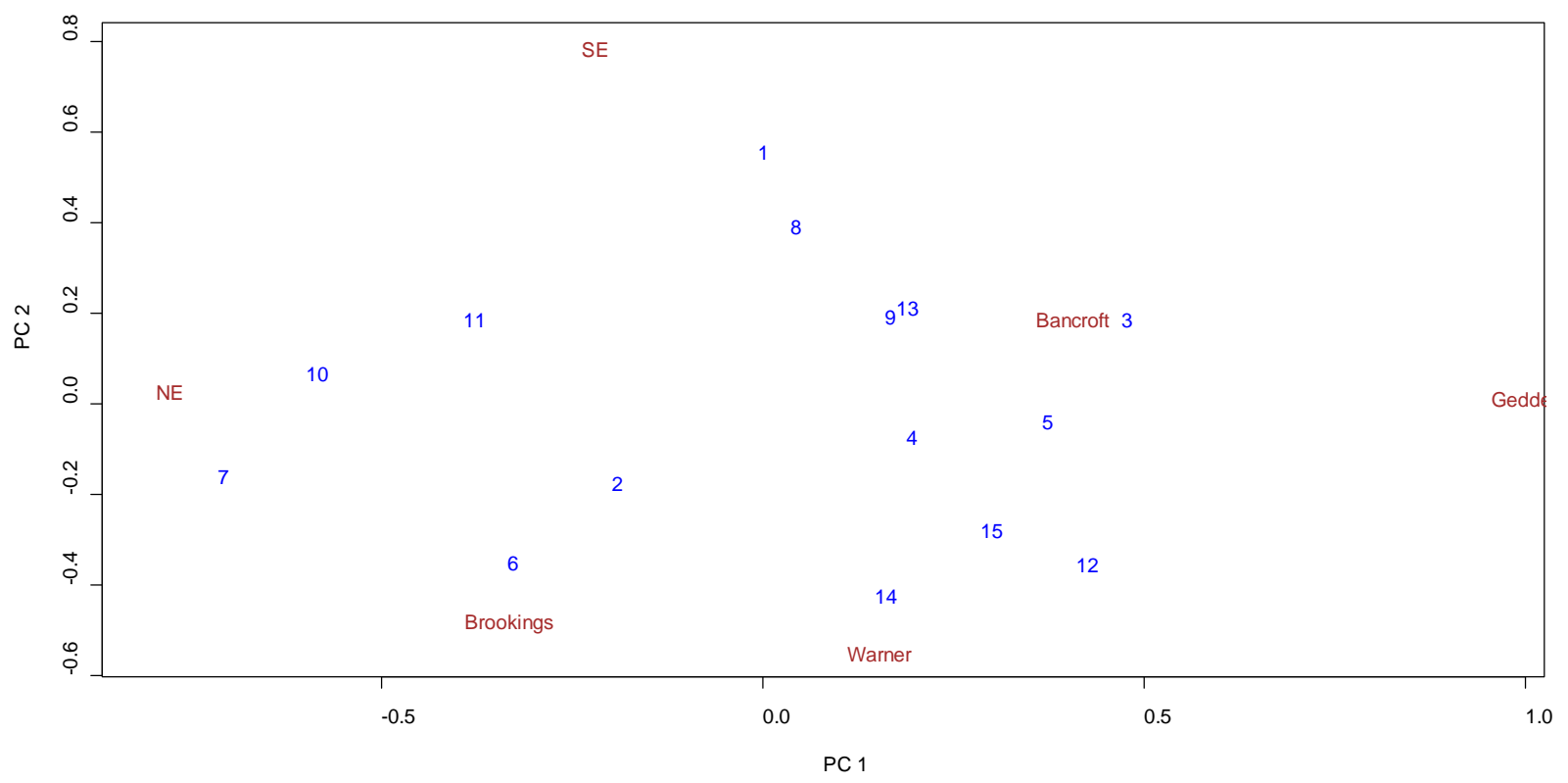

Fig. 6: AMMI 2-Biplot for oil content in soybean 1=HEFTY H12Y12, 2=HEFTY H13Y12, 3=HEFTY H15Y12, 4=HEFTY HY17Y12, 5=HEFTY H18Y12, 6=HEFTY H19Y12, 7=NUTECH 6118, 8=NUTECH 6145, 9=NUTECH 6156, 10 =NORTHSTAR 1257R2, 11=NORTHSTAR 1325R2, 12=NORTHSTAR 1477NR2, 13=NORTHSTAR 1726NR2, 14=NORTHSTAR 7159RR, 15=SD 2171 